\title{
Management of Valsa Canker on Apple with Adjustments to Potassium Nutrition
}

H. X. Peng, X. Y. Wei, and Y. X. Xiao, State Key Laboratory of Crop Stress Biology for Arid Areas and College of Plant Protection, Northwest A\&F University, Yangling, Shaanxi, 712100, China; Y. Sun, Faculty of Science, National University of Singapore, Singapore 117543; A. R. Biggs, Kearneysville Tree Fruit Research and Education Center, West Virginia University, Kearneysville 25443; M. L. Gleason, Department of Plant Pathology and Microbiology, Iowa State University, Ames 50011; and S. P. Shang, M. Q. Zhu, Y. Z. Guo, and G. Y. Sun, State Key Laboratory of Crop Stress Biology for Arid Areas and College of Plant Protection, Northwest A\&F University

\begin{abstract}
Peng, H. X., Wei, X. Y., Xiao, Y. X., Sun, Y., Shang, S. P., Biggs, A. R., Gleason, M. L., Zhu, M. Q., Guo, Y. Z., and Sun, G. Y. 2016. Management of Valsa canker on apple with adjustments to potassium nutrition. Plant Dis. 100:884-889.

Valsa canker, caused by the fungus Valsa mali, is one of the most destructive diseases of apple in the primary production areas of China and other East Asian countries. Currently, there are no effective control methods for this disease. We investigated the occurrence of Valsa canker in 24 apple orchards in Shaanxi Province in concert with foliar nutrient analysis, and found that there was a significant negative correlation of leaf potassium $(\mathrm{K})$ content with incidence and severity of Valsa canker.

Fertilization experiments showed that increasing tree $\mathrm{K}$ content enhanced resistance to pathogen colonization and establishment. Apple trees with leaf $\mathrm{K}$ content greater than $1.30 \%$ exhibited almost complete resistance to Valsa mali. Field trials demonstrated that increasing K fertilization could significantly reduce disease incidence. Improved management of tree nutrition, especially K content, could effectively control the occurrence and development of Valsa canker.
\end{abstract}

Valsa canker, caused by the fungus Valsa mali Miyabe \& G. Yamada (Wang et al. 2011), is one of the most destructive diseases of apple in eastern Asia, seriously impeding apple production in China (Cao et al. 2009), Japan (Abe et al. 2011), and Korea (Vasilyeva and Kim 2000). This disease is epidemic in the primary appleproducing areas in China, and is a severe threat to the economic viability of apple production (Cao et al. 2009). Data collected by the Apple Research \& Development Center, China Agriculture Research System (Cao et al. 2009), showed that the average incidence of Valsa canker was $52.7 \%$ across all tree ages and, in some areas, it was $85 \%$ in 2008 .

The pathogen is usually considered to be weakly pathogenic and preferentially colonizes through wounds such as pruning cuts or fruit scars (Willison 1936). Infection can take place throughout the year, and pathogen colonization produces localized cankers that kill twigs, limbs, and, finally, the entire tree (Abe et al. 2007). Because V. mali penetrates into the host phloem and xylem, resulting in a perennial canker (Tamura and Saito 1982), fungicide application is ineffective (Abe et al. 2011). All commercially important apple varieties are susceptible to the pathogen (Bessho et al. 1994). Although numerous management approaches have been implemented to try to limit Valsa canker, including attempts at physical, chemical, and biological control, the disease remains prevalent. It is clear that new strategies to manage Valsa canker are needed and a better understanding of host-pathogen relations is required.

Mineral nutrition can exert a profound effect on disease development, with fertilizer application increasing or decreasing development of diseases caused by different pathogens (Walters and Bingham 2007). All the essential nutrients can influence disease severity by affecting host resistance or susceptibility to pathogens, the host-pathogen histological or morphological structure or properties, the function of tissues to hasten or slow pathogenesis, and the apparent virulence and ability of pathogens to survive (Huber and Graham 1999; Munson 1985). Nutrient status is often a determining factor in disease development and plants with optimal nutritional status often have the highest resistance to disease. Leaf nutrient analysis is a valid

Corresponding author: G. Y. Sun; E-mail: sgy@nwsuaf.edu.cn

Accepted for publication 20 November 2015.

http://dx.doi.org/10.1094/PDIS-09-15-0970-RE

(C) 2016 The American Phytopathological Society approach to evaluate the nutritional status of trees in orchards and has been widely used to help researchers study the behavior of perennial crops (Uexkull 1968).

At present, there are few reports on the relationship between incidence and severity of Valsa canker and tree nutrition on apple. Our objective was to investigate the occurrence of Valsa canker and analyze leaf nutrient status from different apple orchards in the major apple-producing areas of Shaanxi to determine whether a relationship exists between disease occurrence and tree nutrient status. Our goal was to better understand the reason for the prevalence of Valsa canker and provide a theoretical basis for its control.

\section{Materials and Methods}

Plant and fungal materials. Twenty-four apple orchards (designated A through X) with differing severity of Valsa canker were selected in Baishui County, Shaanxi Province, with 15- to 25-year-old trees of Malus domestica 'Fuji' on M.26 rootstock. In addition, field and potted-tree experiments using 2-year-old Fuji trees on M.9 rootstock were conducted in Yangling, Shaanxi, China.

A highly virulent strain of $V$. mali Xyx10 was isolated from infected apple tree bark from an orchard in Shaanxi Province. The pathogenicity of the isolate was ascertained and its internal transcribed spacer sequence was submitted to the National Center for Biotechnology Information (KT596727). The isolate was cultivated on potato dextrose agar (PDA) at $25^{\circ} \mathrm{C}$ with continuous light until pycnidia formed and conidia were harvested (Zang et al. 2012).

Valsa canker incidence and severity. A survey for Valsa canker was carried out from 13 to 15 March 2012. Thirty apple trees per orchard were selected according to a "Z" sampling scheme and, for each tree, we measured tree limb circumference, number of cankers per tree, and canker position, length, and width.

The rating system used by Biggs and Miles (1988) for Leucostoma canker of peach was revised as follows: $0=$ no canker observed; $1=$ one canker in 1- or 2-year-old branches; $2=$ no canker observed in trunk or major limbs of tree, two, or three cankers in 1- or 2-yearold branches; 3 = one canker in trunk or major limbs, width $<30 \%$ of the girth, or multiple cankers, cumulative width (nonoverlapping) $<30 \%$ of the girth; $4=$ one canker in trunk or major limbs, $30 \%<$ canker width $<50 \%$ of the girth, or multiple cankers, $30 \%<$ cumulative width (nonoverlapping) $<50 \%$ of the girth; $5=$ one canker in trunk or major limbs, width $>50 \%$ of the girth, or multiple cankers, cumulative width (nonoverlapping) $>50 \%$ of the girth; $6=$ two cankers in trunk or major 
limbs, each width $>50 \%$ of the girth, respectively; $7=$ three cankers in trunk or major limbs, each width $>50 \%$ of the girth, respectively; $8=$ tree dying, canker judged to be the major cause of dying; and $9=$ tree death, canker judged to be the major cause of death.

A disease index (DI) that represented both disease incidence and symptom severity was calculated as $(\Sigma D i \times D d) /(M i \times M d) \times 100$, where $D i$ is sum of number of unhealthy trees at each severity grade, $D d$ is the grade's representative value, $M i$ is the total number of trees, and $M d$ is the representative value of the highest severity grade.

Disease incidence was calculated as the number of diseased plants/ the total number of plants $\times 100 \%$.

Greenhouse fertilization trial. Fuji trees on M.26 rootstock were planted in vermiculite in clay containers $(30 \mathrm{~cm}$ in diameter by $30 \mathrm{~cm}$ in height). Trees were placed in the greenhouse at $25^{\circ} \mathrm{C}$ (day) and $20^{\circ} \mathrm{C}$ (night) with a 13 -h photoperiod and light intensity of $300 \mu \mathrm{mol}$ $\mathrm{m}^{-2} \mathrm{~s}^{-1}$ for 6 months before inoculation. Beginning on 1 March 2013, trees were randomly assigned to one of four potassium $(\mathrm{K})$ treatments $\left(0,5,10\right.$, or $15 \mathrm{mM} \mathrm{K}$ from potassium nitrate $\left.\left[\mathrm{KNO}_{3}\right]\right)$ and each $\mathrm{K}$ treatment was replicated five times (three trees each) in a completely randomized design. The trees were fertigated once a week for 6 months with a modified Hoagland's solution at 1,000 ml/pot (Hoagland and Arnon 1950).

Orchard fertilization trials. Fertilization trials were conducted during the growing season (April to September) in 2011 and repeated in 2012 and 2013 in the experimental orchard (Fuji trees on M.9 rootstock, 3 years old in 2011) in Yangling, Shaanxi. There were four treatments: treatment $1=$ no fertilizer, treatment $2=$ dissolved potassium sulfate $(0.5 \%)$ sprayed on the leaves in six applications at 10 - to 15-day intervals from early June to August (the equivalent of potassium oxide $\left[\mathrm{K}_{2} \mathrm{O}\right]$ at $11.25 \mathrm{~g} /$ tree in total), treatment $3=$ four applications of a mixture of soluble monopotassium phosphate $(98 \%)$ and carbamide urea via drip irrigation at 30-day intervals from early May to August (the equivalent of $54.6 \mathrm{~g}$ of nitrogen [N], $61.2 \mathrm{~g}$ of phosphorus pentoxide $\left[\mathrm{P}_{2} \mathrm{O}_{5}\right]$, and $40.0 \mathrm{~g}$ of $\mathrm{K}_{2} \mathrm{O}$ per tree in total), and treatment $4=$ treatment 2 plus treatment 3 . Each treatment unit contained five trees with three replications. The treatment design was a randomized complete block.

Inoculation. Inoculations were performed in mid-September for the field and greenhouse fertilization treatments. Five 1-year-old branches per tree were selected to create four circular wounds per branch, $20 \mathrm{~cm}$ apart, using a 5 -mm-diameter cork borer. The wounds penetrated to the depth of the xylem; the phloem tissues and bark were removed and discarded, and the perimeter of the wound was disinfested with $70 \%$ ethanol. After 5 min for ethanol volatilization, a mycelial plug was placed in each wound (hyphae placed toward the xylem surface), then tightly wrapped with sealing film, which was removed 7 days later. Wounded branches covered with noncolonized PDA plugs served as the control treatment.

Nutritional analysis. To determine tree nutrient status, 10 trees were sampled according to a " $Z$ " scheme in each of the 24 surveyed orchards. Fully developed, healthy-appearing leaves from currentyear shoots selected from the middle parts of the outer tree crown were collected in early August. Twelve leaves were picked from the four cardinal points of each tree. From each of these orchards, 120 leaves were mixed and packed into Kraft paper bags. In the greenhouse and experimental orchard, 40 leaves were taken from the four cardinal points of each tree in early August. All leaf samples were processed in accordance with the sampling guidelines described by Stiles and Reid (1991). Total N content was determined using a Kjeldahl total N apparatus (KDY-9830; Huawei Industrial Technology, Beijing), flame photometry (Z-2000; Hitachi, Tokyo) was used for analysis of $\mathrm{K}$ content, and phosphorus $(\mathrm{P})$ concentration was determined by Mo-Sb antispectrophotometery (UV-2450; Shimadzu, Kyoto, Japan).

Demonstration trials in commercial orchards. Three orchards were selected for fertilization demonstration trials in Baishui. In orchards 1 (22-year-old Fuji apple orchard) and 2 (26-year old Fuji orchard), $4.0 \mathrm{~kg}$ of $5 \% \mathrm{~K}_{2} \mathrm{O}$ potassium humate fertilizer (Double Dragons Humic Acid Co. Ltd., Xinjiang, China) and $1.0 \mathrm{~kg}$ of potassium sulfate $(51 \%)$ were applied to the soil around each tree twice a year, in spring and autumn, from 2012 to 2014. Fertilizer was applied by initially digging six holes, each $40 \mathrm{~cm}$ deep by $30 \mathrm{~cm}$ by $30 \mathrm{~cm}$, in the soil beneath the canopy of each tree and then burying an equal amount of the fertilizer in each hole. In orchard 3 (25-year-old Fuji trees), each tree received $3.0 \mathrm{~kg}$ of $40 \%$ organic matter of NPK Humate Compound Fertilizer $\left(8 \% \mathrm{~N}+\mathrm{P}_{2} \mathrm{O}_{5}+\mathrm{K}_{2} \mathrm{O}\right.$; Weinan Humic Acid Factory of Shaanxi, Weinan, China) and $2.0 \mathrm{~kg}$ of potassium sulfate fertilizer $(51 \%)$ twice a year in spring and fall from 2011 to 2014. Disease incidence and number of cankers were quantified annually in midMay. For all orchards in spring and autumn, all diseased bark in the vicinity of cankers was removed surgically along with 2 to $3 \mathrm{~cm}$ of surrounding healthy bark, then covered with $25 \%$ propiconazole EC at $75 \mu \mathrm{g} / \mathrm{ml}$ (Shannxi Sunger Road Bio-Science Co. Ltd., Xi' an, China) painted on by brush to provide protection against fungal infection.

Data analysis. Data on canker incidence and severity were processed by SPSS19.0 and EXCEL2003 for analysis of variance and regression analysis. The Fisher's least significant difference test was used for separation of means.

\section{Results}

Apple leaf $\mathbf{N}, \mathbf{P}$, and $\mathrm{K}$ content. In most orchards, $\mathrm{N}$ content of leaves (2.03 to $2.84 \%$ ) was within a normal range, with only a few orchards showing $\mathrm{N}$ values above the normal range. $\mathrm{P}$ content $(0.22$ to $0.33 \%$ ) also was within a normal range. $\mathrm{K}$ content varied from 0.58 to $1.32 \%$, and was in the deficient range in all orchards except one (Table 1).

Valsa canker incidence and severity. Most apple trees were affected by Valsa canker but there was significant variation in incidence among orchards. DI ranged from 0 to 25.2 and disease incidence (percent symptomatic trees) ranged from 0 to $50.0 \%$ (Table 1 ).

Macronutrient concentration and disease severity relationships. There was no significant linear relationship between DI and leaf $\mathrm{N}$ or $\mathrm{P}$ content (Table 2). However, a significant inverse relationship occurred

Table 1. Apple foliar nitrogen $(\mathrm{N})$, phosphorus $(\mathrm{P})$, and potassium $(\mathrm{K})$ levels, disease severity rating, and disease incidence from 24 orchards that were investigated

\begin{tabular}{|c|c|c|c|c|c|}
\hline \multirow{2}{*}{$\begin{array}{l}\text { Orchard } \\
\text { code }\end{array}$} & \multicolumn{3}{|c|}{ Nutrition levels $^{x}$} & \multicolumn{2}{|c|}{ Disease development ${ }^{y}$} \\
\hline & $\mathrm{N}(\%)$ & $\mathrm{P}(\%)$ & $\mathbf{K}(\%)$ & Disease index ${ }^{z}$ & Disease incidence $(\%)$ \\
\hline A & 2.18 & 0.26 & 0.58 & 25.2 & 50 \\
\hline B & 2.03 & 0.22 & 0.61 & 22.3 & 43.3 \\
\hline $\mathrm{C}$ & 2.17 & 0.26 & 0.65 & 21.1 & 33.3 \\
\hline $\mathrm{D}$ & 2.36 & 0.32 & 0.75 & 12.1 & 31.8 \\
\hline $\mathrm{E}$ & 2.52 & 0.33 & 0.75 & 19.6 & 40 \\
\hline $\mathrm{F}$ & 2.07 & 0.29 & 0.75 & 20.7 & 43.3 \\
\hline $\mathrm{G}$ & 2.29 & 0.27 & 0.76 & 16.3 & 40 \\
\hline $\mathrm{H}$ & 2.33 & 0.29 & 0.76 & 16.7 & 43.3 \\
\hline I & 2.41 & 0.26 & 0.77 & 18.4 & 43.3 \\
\hline $\mathrm{J}$ & 2.26 & 0.22 & 0.77 & 6.7 & 16.6 \\
\hline $\mathrm{K}$ & 2.32 & 0.25 & 0.86 & 10.4 & 16.6 \\
\hline $\mathrm{L}$ & 2.4 & 0.27 & 0.89 & 1.1 & 3.3 \\
\hline M & 2.84 & 0.28 & 0.91 & 1.5 & 3.3 \\
\hline $\mathrm{N}$ & 2.07 & 0.33 & 1.02 & 0 & 0 \\
\hline $\mathrm{O}$ & 2.21 & 0.22 & 1.05 & 2.6 & 6.8 \\
\hline $\mathrm{P}$ & 2.37 & 0.23 & 1.15 & 1.1 & 3.3 \\
\hline Q & 2.44 & 0.26 & 1.16 & 1.6 & 3.3 \\
\hline $\mathrm{R}$ & 2.33 & 0.22 & 1.18 & 1.1 & 3.3 \\
\hline $\mathrm{S}$ & 2.69 & 0.24 & 1.18 & 1.1 & 3.3 \\
\hline $\mathrm{T}$ & 2.17 & 0.25 & 1.23 & 1.5 & 3.3 \\
\hline $\mathrm{U}$ & 2.5 & 0.25 & 1.24 & 0 & 0 \\
\hline $\mathrm{V}$ & 2.52 & 0.24 & 1.24 & 1.1 & 3.3 \\
\hline W & 2.49 & 0.23 & 1.25 & 0 & 0 \\
\hline X & 2.62 & 0.24 & 1.32 & 0 & 0 \\
\hline
\end{tabular}

$\mathrm{x}$ Nutrition levels determined from 12 leaves per tree, 10 trees from each of the 24 surveyed orchards.

y Data are from 30 apple trees per orchard.

${ }^{\mathrm{z}}$ Disease index $(\mathrm{DI})$ was calculated as DI $=(\Sigma D i \times D d) /(M i \times M d) \times 100$, where $D i$ is sum of number of unhealthy trees at each grade, $D d$ is the grade's representative value, $M i$ is the total number of trees, and $M d$ is the representative value of the highest grade. 
between $\mathrm{K}$ content and DI $\left(y=40.67-33.89 x_{\mathrm{K}}, R^{2}=0.7851, P<0.01\right.$; Table 2, Fig. 1). When leaf $K$ was 0.5 to 0.6 , the disease severity rating was $>20.0$, and the orchard with the highest DI (25.2) had the lowest $\mathrm{K}$ content $(0.58 \%)$. When leaf $\mathrm{K}$ was 0.7 to 0.8 , the DI values of most orchards ranged from 10.0 to 20.0 . Of the 11 orchards with leaf $\mathrm{K}$ content above $0.9 \%, 3$ had no canker, the others showed light canker development, and all DI values were $<5.0$. There were significant differences $(P<0.03)$ between the three levels of leaf $\mathrm{K}$ content $(0.5$ to $0.6,0.7$ to 0.8 , and $>0.9 \%$ ) and the DI values (Table 3 ).

Effects of macronutrient ratios on DI. We calculated the N/P, $\mathrm{N} / \mathrm{K}$, and $\mathrm{P} / \mathrm{K}$ ratios and determined their relationship to canker DI. The results confirmed that the relationship between N/P and DI was not significant (data not shown), whereas the DI relationships with $\mathrm{N} / \mathrm{K}$ and $\mathrm{P} / \mathrm{K}$ were highly significant $(P<0.01)$ (Figs. 2 and 3 ).

There was a significant positive relationship between the $\mathrm{N} / \mathrm{K}$ ratio and DI $\left(y=-26.089+13.209 x_{\mathrm{N} / \mathrm{K}}, R^{2}=0.7361, P<0.01\right.$; Fig. 2$)$. The ratio of N/K ranged from 1.76 to 3.79 . Among the 24 orchards, only 3 were $<2$ ( $\mathrm{T}, \mathrm{W}$, and $\mathrm{X}), 12$ orchards ranged from 2 to 3 , and 9 orchards were $>3$. The ratio of $\mathrm{N} / \mathrm{K}$ for $87.5 \%$ of the sampled orchards (21 of 24) was $>2$.

The ratio of $\mathrm{P} / \mathrm{K}$ and canker DI also showed a significant positive relationship $\left(y=-16.209+84.097 x_{\mathrm{P} / \mathrm{K}}, R^{2}=0.7461, P<0.01\right.$; Fig. $3)$. The ratio values ranged from 0.18 to 0.45 among orchards. When the ratio of $\mathrm{P} / \mathrm{K}$ was $<0.25$, the DI values were all lower and $<5$, but if the $\mathrm{P} / \mathrm{K}$ ratio was greater than 0.33 , the $\mathrm{DI}$ values were higher.

Greenhouse fertilization trials. After 6 months of fertilization, leaves of potted trees receiving the four treatments exhibited similar levels of $\mathrm{N}$ and $\mathrm{P}$, whereas K content was $0.45,0.67,1.30$, and $1.75 \%$ in treatments 1 through 4 , respectively. Seven days after inoculation, trees with $0.45 \%$ leaf $\mathrm{K}$ had the longest average canker length, about $3.84 \mathrm{~cm}$, and the trees with $0.67 \%$ leaf $\mathrm{K}$ had $1.93 \mathrm{~cm}$ average canker length. When K content was $1.30 \%$ or higher, trees showed very limited infection and, when infection occurred, it was limited to the inoculation site. At 14 days after inoculation, average canker length on trees with $0.45 \%$ leaf $\mathrm{K}$ had extended to $13.46 \mathrm{~cm}$ compared with $7.38 \mathrm{~cm}$ for trees with $0.67 \%$ leaf $\mathrm{K}$. The trees with 1.30 and $1.75 \%$ leaf $\mathrm{K}$ had not developed canker lesions (Fig. 4).

Orchard fertilization trials. Among the treatments in the field experiment, the content of $\mathrm{N}$ and $\mathrm{P}$ was similar (Table 4). In contrast, foliar $\mathrm{K}$ was $0.75 \%$ in the no-fertilizer treatment (treatment 1 ), which showed the longest lesions, approximately $7.06 \mathrm{~cm}$. There was no significant difference $(P>0.667)$ in leaf $\mathrm{K}$ content between fertilizer

Table 2. Regression analysis showing the relationship between disease index of Valsa canker and nitrogen $(\mathrm{N})$, phosphorus $(\mathrm{P})$, and potassium $(\mathrm{K})$ contents from leaf analysis

\begin{tabular}{llcr}
\hline Nutrient element & Regression equation $^{\mathbf{z}}$ & $\boldsymbol{R}^{2}$ & $\boldsymbol{P}$ value \\
\hline $\mathrm{N}$ & $y=57.80-20.94 x_{\mathrm{N}}$ & 0.2153 & 0.019 \\
$\mathrm{P}$ & $y=-11.98+78.61 x_{\mathrm{P}}$ & 0.0834 & 0.171 \\
$\mathrm{~K}$ & $y=40.67-33.89 x_{\mathrm{K}}$ & 0.7851 & $<0.001$ \\
\hline
\end{tabular}

z Symbols: $y=$ disease index (DI) of Valsa canker, $x_{\mathrm{N}}=$ leaf $\mathrm{N}$ concentration $(\%), x_{\mathrm{P}}=$ leaf $\mathrm{P}$ concentration (\%), and $x_{\mathrm{K}}=$ leaf $\mathrm{K}$ concentration (\%). DI was calculated as DI $=(\Sigma D i \times D d) /(M i \times M d) \times 100$, where $D i$ is sum of number of unhealthy trees at each grade, $D d$ is the grade's representative value, $M i$ is the total number of trees, and $M d$ is the representative value of the highest grade.

Table 3. Analysis of leaf potassium $(\mathrm{K})$ groups showing the impact of leaf $\mathrm{K}$ content $(\%)$ on disease index (DI)

\begin{tabular}{lc}
\hline Leaf K content $(\%)$ & \multicolumn{1}{c}{$\mathbf{D I}^{\mathbf{z}}$} \\
\hline 0.5 to 06 & $>20 \mathrm{a}$ \\
0.7 to 0.8 & 10 to $20 \mathrm{~b}$ \\
0.9 to 1.3 & $<10 \mathrm{c}$ \\
\hline
\end{tabular}

${ }^{\mathrm{z}}$ DI was calculated as DI $=\left(\sum D i \times D d\right) /(M i \times M d) \times 100$, where $D i$ is sum of number of unhealthy trees at each grade, $D d$ is the grade's representative value, $M i$ is the total number of trees, and $M d$ is the representative value of the highest grade. Values not followed by the same letters differ significantly $(P=0.05)$ according to Fisher's least significant difference test. application to leaves alone (treatment 2) and root application (treatment 3 ) but the K content was higher in comparison with no fertilizer. The K content of treatments 2 and 3 was 1.16 and $1.17 \%$, respectively, and canker length was approximately half of that in treatment 1 (3.64 and $3.40 \mathrm{~cm}$, respectively). K content in treatment 4 (foliar spray plus root application) was $1.37 \%$ and lesion length was $0.09 \mathrm{~cm}$.

Orchard demonstration trials. $\mathrm{K}$ fertilization significantly reduced the incidence and severity of Valsa canker (Fig. 5). In orchard 1, before fertilization in March 2012, the incidence of diseased trees was $58.1 \%$. One year later, after $\mathrm{K}$ fertilization, disease incidence was reduced to $12.9 \%$, then declined to $2.1 \%$ in 2014 . In orchard 2 , incidence of Valsa canker during the peak period in 2012, 2013, and 2014 was $78.1,7.6$, and $8.1 \%$, respectively. In orchard 3, disease incidence declined from $96 \%$ in 2011 to $21.2 \%$ in $2012,15.7 \%$ in 2013 , and $5.1 \%$ in 2014.

\section{Discussion}

$\mathrm{K}$ is reported to decrease disease severity in many host plants, including diseases caused by biotrophic and necrotrophic pathogens (Walters and Bingham 2007). In many cases, K-deficient plants tend to be more susceptible to infection than plants receiving an adequate supply of K (Wang et al. 2013). Perrenoud (1990) reviewed almost 2,450 literature references on $\mathrm{K}$ and plant health, and concluded that use of $\mathrm{K}$ decreased the incidence of fungal diseases in the majority of cases. Wang et al. (1997) determined the K concentration of 'Ralls Genet' bark before spring budding, and the results suggested that $\mathrm{K}$ content exhibited a significant correlation with severity of Valsa canker.

Our study demonstrated that K-deficient apple trees were more susceptible to infection by $V$. mali and that increasing the K content of apple trees can reduce the incidence and severity of Valsa canker. In the experiments, we found that there was a significant negative relationship between the severity of Valsa canker and $\mathrm{K}$ content in the commercial orchards. Fertilization experiments with potted and field-grown trees showed that tree resistance to pathogen colonization increased as leaf $\mathrm{K}$ increased. It is noteworthy that, when leaf

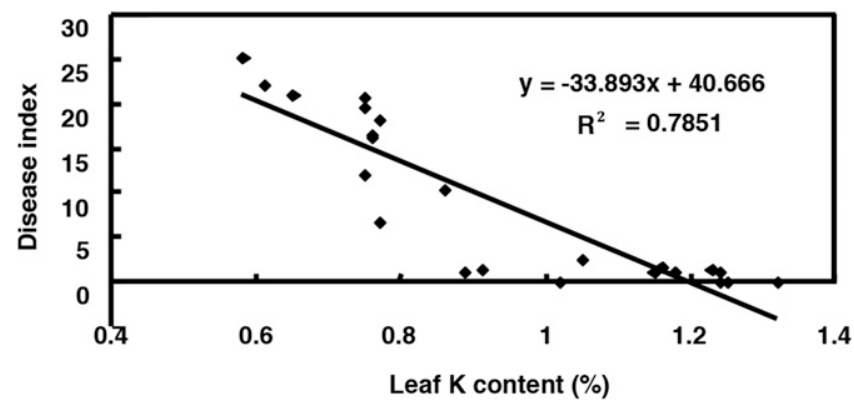

Fig. 1. Relationship between apple leaf potassium $(K)$ content and Valsa canker disease index. Each data point represents leaf $\mathrm{K}$ and disease index from 24 orchards sampled in 2012.

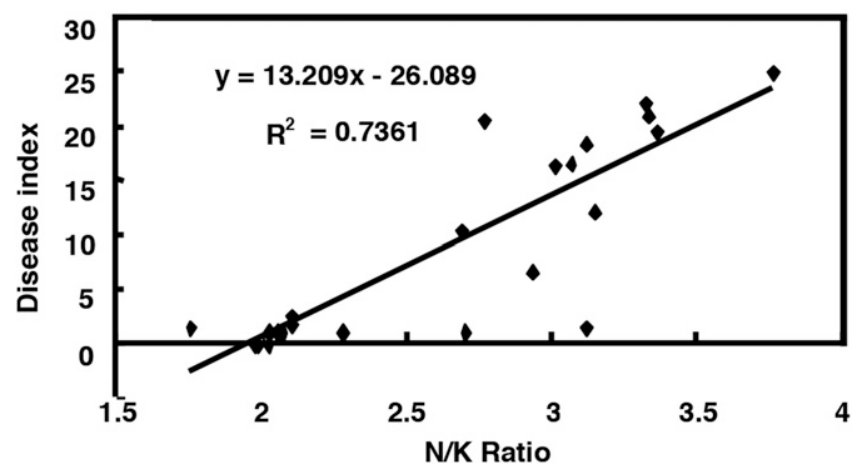

Fig. 2. Relationship between nitrogen/potassium (N/K) ratio and disease index. Each data point represents leaf $N / K$ ratio and disease index from 24 orchards sampled in 2012. 
$\mathrm{K}$ content was greater than $1.30 \%$, infection was limited or absent altogether, indicating that apple trees have relative resistance to the canker pathogen until a low K content threshold occurs, below which the trees become increasingly susceptible.

Judicious use of $\mathrm{K}$ fertilizer is associated with vigorous tree growth and high yields of marketable apple fruit (Stiles and Reid 1991). In most areas where apple fruit are produced, the concentration of leaf $\mathrm{K}$ ranges from 1.3 to $1.8 \%$ (Marschner 2012). Our analysis for orchards in Baishui showed that leaf $\mathrm{K}$ content of most orchards was deficient, with only one orchard exhibiting a normal level (>1.3\%).

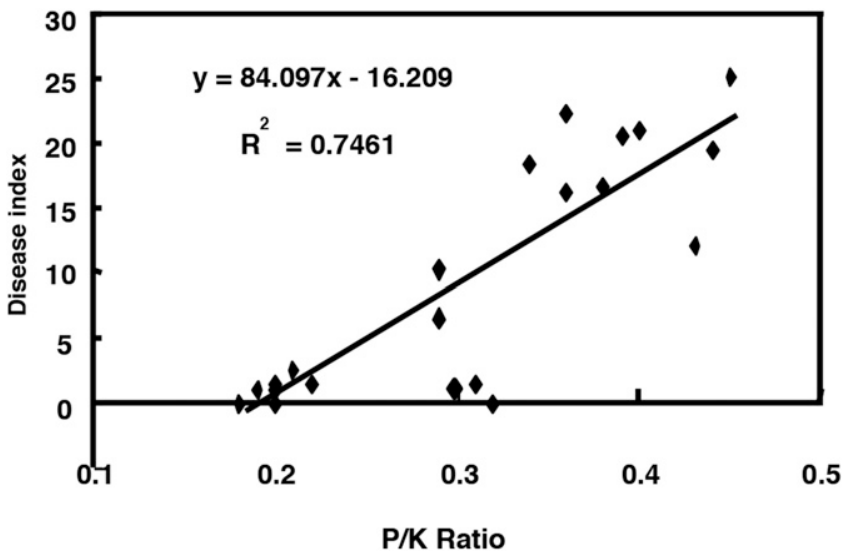

Fig. 3. Relationship between phosphorus/potassium $(P / K)$ ratio and disease index. Each data point represents leaf $\mathrm{P} / \mathrm{K}$ ratio and disease index from 24 orchards sampled in 2012.
When leaf $\mathrm{K}$ was below the normal level, and especially when it was $<0.9 \%$, orchards exhibited severe Valsa canker. However, when leaf $\mathrm{K}$ was $>0.9 \%$, disease incidence declined significantly, with the DI reduced from 25.2 to 1.5 . It is notable that, in orchards where leaf $\mathrm{K}$ reached the normal level $(>1.3 \%)$, only a few Valsa canker infections were found. This finding was confirmed by the fertilization experiments. Trees with normal $\mathrm{K}$ levels (1.3 to $1.8 \%$ ) were only minimally infected at the inoculation site and canker extension was not observed in those trees. When leaf $\mathrm{K}$ was below normal, cankers extended in length quite rapidly. The above results showed that proper management of orchard $\mathrm{K}$ levels could effectively control the occurrence of Valsa canker.

Table 4. Leaf nutrient content, nutrient content ratios, and Valsa canker lesion length from three orchard fertilization trials ${ }^{\mathrm{y}}$

\begin{tabular}{ccccccc}
\hline Treatment $^{\mathbf{z}}$ & $\mathbf{N}(\boldsymbol{\%})$ & $\mathbf{P}(\boldsymbol{\%})$ & $\mathbf{K}(\boldsymbol{\%})$ & $\mathbf{N} / \mathbf{K}$ & $\mathbf{P} / \mathbf{K}$ & $\begin{array}{c}\text { Lesion } \\
\text { length }(\mathbf{c m})\end{array}$ \\
\hline Treatment 1 & $2.25 \mathrm{a}$ & $0.25 \mathrm{a}$ & $0.75 \mathrm{a}$ & $3.00 \mathrm{a}$ & $0.33 \mathrm{a}$ & $7.06 \mathrm{a}$ \\
Treatment 2 & $2.36 \mathrm{~b}$ & $0.26 \mathrm{a}$ & $1.16 \mathrm{~b}$ & $2.03 \mathrm{~b}$ & $0.22 \mathrm{~b}$ & $3.64 \mathrm{~b}$ \\
Treatment 3 & $2.43 \mathrm{c}$ & $0.27 \mathrm{a}$ & $1.17 \mathrm{~b}$ & $2.08 \mathrm{~b}$ & $0.23 \mathrm{~b}$ & $3.40 \mathrm{c}$ \\
Treatment 4 & $2.34 \mathrm{~b}$ & $0.28 \mathrm{a}$ & $1.37 \mathrm{c}$ & $1.71 \mathrm{c}$ & $0.20 \mathrm{~b}$ & $0.09 \mathrm{~d}$ \\
\hline
\end{tabular}

y Data for nitrogen $(\mathrm{N})$, phosphorus $(\mathrm{P})$, and potassium $(\mathrm{K})$, and lesion length are means of three replicates. Means across rows that are not followed by the same letters differ significantly $(P=0.05)$ according to Fisher's least significant difference test.

${ }^{\mathrm{z}}$ Treatment $1=$ no fertilizer, treatment $2=$ dissolved potassium sulfate sprayed on the leaves, treatment $3=$ mixed soluble monopotassium phosphate and carbamide urea applied through drip irrigation, and treatment $4=$ treatment 2 plus treatment 3 .
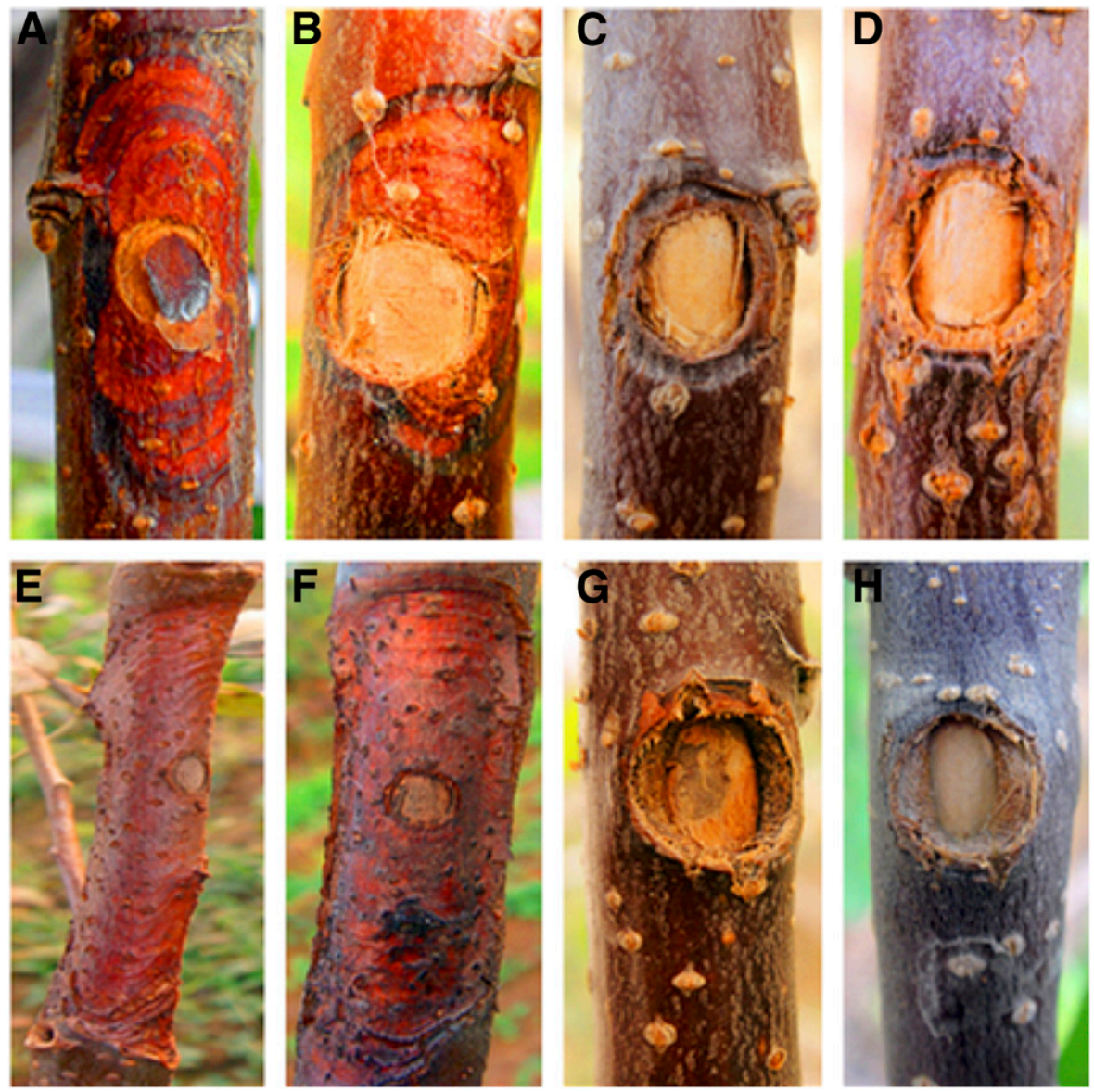

Fig. 4. Effects of different leaf potassium (K) content (\%) on apple canker development in the potted tree inoculation experiment showing significantly reduced pathogen colonization at 1.30 and $1.75 \%$ leaf $K$ at 7 and 14 days postinoculation. $\mathbf{A}$ to $D$, Canker on $0.45,0.67,1.30$, and $1.75 \%$ leaf $K$ content trees 7 days after inoculation, respectively. $E$ to $H$, Canker on $0.45,0.67,1.30$, and $1.75 \%$ leaf $\mathrm{K}$ content trees 14 days after inoculation, respectively. 
The ratio between $\mathrm{N}$ and $\mathrm{K}$ plays a role in host-pathogen interactions. An unbalanced ratio of N/K has resulted in aggravation of many plant diseases (Flückiger and Braun 2003). When the ratio of $\mathrm{N} / \mathrm{K}$ exceeded 2.5, apple susceptibility to Venturia inaequalis was increased significantly (Chaboussou 1972) and, if the ratio of N/K was more than 3.7, branch death on beech (Fagus sylvatica) caused by Nectria ditissima increased significantly (Flückiger and Braun 2003; Flückiger et al. 1986). For Valsa canker on apple, we found that the DI gradually increased as the ratio of N/K increased; especially when the ratio of $\mathrm{N} / \mathrm{K}$ exceeded 2.5 , the DI values were generally high. An imbalance between $\mathrm{P}$ and $\mathrm{K}$ also favored Valsa canker, with incidence decreasing when the ratio of $\mathrm{P} / \mathrm{K}$ decreased (i.e., when $\mathrm{P} / \mathrm{K}<0.25$, the DI decreased to $<5$ ). Consequently, from the perspective of Valsa canker management, producers should maintain the foliar $\mathrm{N} / \mathrm{K}$ and $\mathrm{P} / \mathrm{K}$ ratios at $<2.5$ and $<0.25$, respectively.

The mechanisms for the observed $\mathrm{K}$ effects on Valsa canker may operate indirectly through their effects on apple tree vigor. The Valsa canker pathogen is usually considered to be weakly pathogenic, colonizing through wounds such as pruning cuts or fruit scars (Willison 1936). It infects and becomes established in the wounds of weak trees but not in those of vigorous trees (Biggs 1989). In general, keeping tree growth vigorous is critical to lower the chance of infection for most woody plant canker diseases. In apple, sufficient vigor is indicated by annual terminal growth of 20.3 to $30.5 \mathrm{~cm}$ for nonspur varieties and 15.2 to $20.3 \mathrm{~cm}$ for spur varieties (Stiles and Reid 1991). Results from a fertigation study initiated with trees planted in 1993 and deblossomed during the first two seasons showed a significant increase in shoot growth in response to K (Stiles 1998). K deficiency can cause small leaves, thin canopy, fine branches, reduced shoot growth, slender shoots, and weak spurs; in severe cases, the shoots may exhibit dieback, all of which reduces tree vigor and increases susceptibility to various diseases (Stiles 1999). As a consequence, we hypothesized that reduced tree vigor caused by $\mathrm{K}$ deficiency resulted in increased incidence of Valsa canker in those orchards with low $\mathrm{K}$ content, and the trees with adequate $\mathrm{K}$ were more vigorous and more resistant to the canker pathogen.

Valsa canker has been devastating in China during the past decade, threatening to hold back development of the Chinese apple industry. In our investigation, it was found that deficiency of leaf K occurred in most orchards in Baishui County. An et al. (2004) surveyed the orchards in the primary apple-producing counties in Shaanxi, and found that $\mathrm{K}$ content in most orchards was low, averaging only $0.858 \%$. Wang et al. (2004) found that current applications of K fertilizer were insufficient in many orchards, whereas $\mathrm{N}$ fertilizer application was overused in Shaanxi from 1994 to 2000. Additional surveys have indicated that $\mathrm{K}$ deficiency occurs to various degrees in the primary apple-producing regions in Henan (Liu et al. 2009) and Shandong (Peng and Jiang 2006). We conclude from these

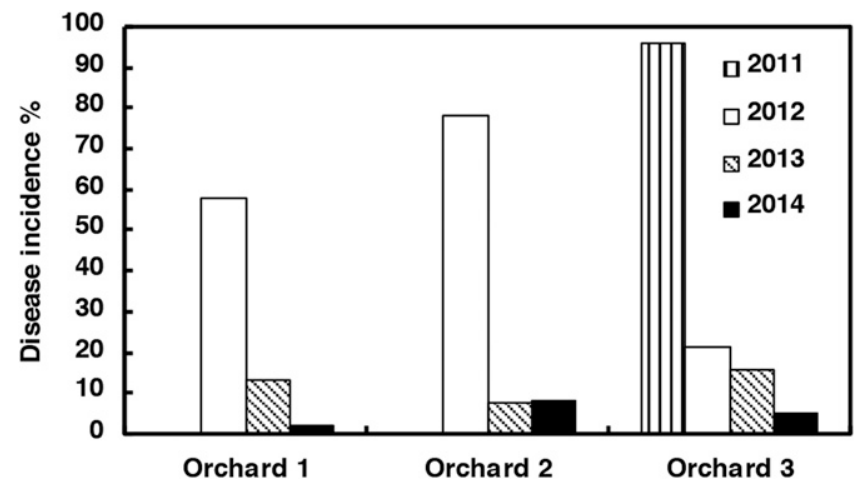

Fig. 5. Effects of three potassium (K) fertilization regimes on incidence of active Valsa canker from the demonstration orchard experiment. In orchards 1 and $2,40.0 \mathrm{~kg}$ of $5 \%$ $\mathrm{K}_{2} \mathrm{O}$ potassium humate fertilizer and $1.0 \mathrm{~kg}$ of potassium sulfate fertilizer $(51 \%)$ were applied to the soil around each tree twice a year, in spring and autumn, from 2012 to 2014. In orchard 3 , each tree received $3.0 \mathrm{~kg}$ of $40 \%$ organic matter of NPK humate compound fertilizer $\left(8 \% \mathrm{~N}+\mathrm{P}_{2} \mathrm{O}_{5}+\mathrm{K}_{2} \mathrm{O}\right)$ and $2.0 \mathrm{~kg}$ of potassium sulfate fertilizer (51\%) twice a year in spring and autumn from 2011 to 2014. surveys that $\mathrm{K}$ deficiency in apple tree is prevalent in most Chinese production regions. Thus, we speculate that unbalanced nutrition in apple, especially $\mathrm{K}$ deficiency, is probably the main reason for the epidemic of Valsa canker in China.

In conclusion, $\mathrm{K}$ plays a significant role in Valsa canker resistance, and improved $\mathrm{K}$ management in apple orchards is expected to reduce or control the occurrence of Valsa canker. Based on our studies, leaf $\mathrm{K}$ content of apple trees should be 0.9 to $1.3 \%$ and the ratio of $\mathrm{N} / \mathrm{K}$ and $\mathrm{P} / \mathrm{K}$ should be maintained at less than 2.5 and 0.25 , respectively. The specific physiological functions of $\mathrm{K}$ and how they affect disease susceptibility or resistance need to be explored further.

\section{Acknowledgments}

We thank Q. Xue (Northwest A\&F University, Shaanxi, China) for his suggestions on fertilizer and orchard trials. This work was supported by the National Natural Science Foundation of China (31371887 and 31171797), the 111 Project from Education Ministry of China (B07049), and China Agriculture Research System (CARS-28). Scientific Article No. 3266 of the West Virginia Agricultural and Forestry Experiment Station, Morgantown.

\section{Literature Cited}

Abe, K., Kotoda, N., Kato, H., and Soejima, J. 2007. Resistance sources to Valsa canker (Valsa ceratosperma) in a germplasm collection of diverse Malus species. Plant Breed. 126:449-453.

Abe, K., Kotoda, N., Kato, H., and Soejima, J. 2011. Genetic studies on resistance to Valsa canker in apple: Genetic variance and breeding values estimated from intra- and inter-specific hybrid progeny populations. Tree Genet. Genomes 7: 363-372.

An, G., Shi, L., Du, Z., Yu, J., Den, F., and Shi, L. 2004. Studies on the standard range of apple leaf nutritional elements in Shaanxi Province. Acta Hortic. Sin. 31:81-83.

Bessho, H., Tsuchiya, S., and Soejima, J. 1994. Screening methods of apple trees for resistance to Valsa canker. Euphytica 77:15-18.

Biggs, A. R. 1989. Integrated approach to controlling Leucostoma canker of peach in Ontario. Plant Dis. 73:869-874.

Biggs, A. R., and Miles, N. W. 1988. Association of suberin formation in uninoculated wounds with susceptibility to Leucostoma cincta and $L$. persoonii in various peach cultivars. Phytopathology 78:1070-1074.

Cao, K., Guo, L., Li, B., Sun, G., and Chen, H. 2009. Investigations on the occurrence and control of apple canker in China. Plant Prot. 35:114-117.

Chaboussou, F. 1972. Die Rolle des Kaliums und des Kationengleichgewichtes für die Widerstandsfähigkeit von Pflanzen gegen Krankheiten. Kali-Briefe 23:1-10.

Flückiger, W., and Braun, S. 2003. Critical limits for nutrient concentrations and ratios for forest trees-a comment. Pages 273-280 in: Empirical Critical Loads for Nitrogen. B. Achermann and R. Bobbink, ed. Swiss Agency for the Environment, Forests and Landscape, Berne, Switzerland.

Flückiger, W., Braun, S., Flückiger-Keller, H., Leonardi, S., Asche, N., Bühler, U., and Lier, M. 1986. Untersuchungen über Waldschäden in festen Buchenbeobachtungsflächen der Kantone Basel-Landschaft, Basel-Stadt, Aargau, Solothurn, Bern, Zürich und Zug. Schweiz. Z. Gesamte Forstwes. 137:917-1010.

Hoagland, D. R., and Arnon, D. I. 1950. The Water-Culture Method for Growing Plants Without Soil. California Agricultural Experiment Station, Berkeley.

Huber, D. M., and Graham, R. D. 1999. The role of nutrition in crop resistance and tolerance to diseases. Pages 169-204 in: Mineral Nutrition of Crops: Fundamental Mechanisms and Implications. Z. Rengel, ed. Food Products Press, London.

Liu, H., Zhang, H., Guo, D., Wang, L., Wang, X., Sun, L., and Kou, T. 2009. Foliar nutrition diagnosis of Red Fuji apple in western Henan Province. J. Nutr. Fert. 15:457-462.

Marschner, P. 2012. Marschner's Mineral Nutrition of Higher Plants. Elsevier Academic Press, Amsterdam.

Munson, R. D. 1985. Potassium in Agriculture. American Society of Agronomy, Madison, WI.

Peng, F., and Jiang, Y. 2006. Characteristics of N, P, and K nutrition in different yield level apple orchards. Sci. Agric. Sin. 39:361-367.

Perrenoud, S. 1990. Potassium and Plant Health. IPI-Research Topics No. 3, 2nd ed. International Potash Institute, Basel, Switzerland.

Stiles, W. C. 1998. Orchard nutrition research. N. Y. Fruit Q. 6:8-10.

Stiles, W. C. 1999. Effects of nutritional factors on regular cropping of apple. HortTechnology 9:328-331.

Stiles, W. C., and Reid, W. S. 1991. Orchard Nutrition Management. Cornell Coop. Ext. Inf. Bull. 219. Cornell University Press, New York.

Tamura, O., and Saito, I. 1982. Histopathological changes of apple bark infected by Valsa ceratosperma (Tode ex Fr.) Maire during dormant and growing periods. Ann. Phytopathol. Soc. Jpn. 48:490-498.

Uexkull, H. R. 1968. Potassium nutrition of tropical crops. Pages 385-421 in: The Role of Potassium in Agriculture. V. J. Kilmar, S. E. Younts, and N. C. Brady, eds. American Society of Agronomy, Madison, WI. 
Vasilyeva, L., and Kim, W. G. 2000. Valsa mali Miyabe et Yamada, the causal fungus of apple tree canker in east Asia. Mycobiology 28:153-157.

Walters, D. R., and Bingham, I. J. 2007. Influence of nutrition on disease development caused by fungal pathogens: Implications for plant disease control. Ann. Appl. Biol. 151:307-324.

Wang, J., Li, M., Zhang, P., and Qiao, Z. 1997. Correlation between potassium content in apple bark in the spring and the occurrence of Valsa canker. Acta Phytophylacica Sin. 25:61-64.

Wang, M., Zheng, Q., Shen, Q., and Guo, S. 2013. The critical role of potassium in plant stress response. Int. J. Mol. Sci. 14:7370-7390.
Wang, S., Ma, W., Xu, W., Li, Q., and Zhang, F. 2004. Evaluation on situation of fertilization for apple in Shaanxi Province. Agric. Res. Arid Areas 22: 146-150.

Wang, X., Wei, J., Huang, L., and Kang, Z. 2011. Re-evaluation of pathogens causing Valsa canker on apple in China. Mycologia 103:317-324.

Willison, R. S. 1936. Peach canker investigations: II. Infection studies. Can. J. Res. 14c:27-44.

Zang, R., Yin, Z., Ke, X., Wang, X., Li, Z., Kang, Z., and Huang, L. 2012. A nested PCR assay for detecting Valsa mali var. mali in different tissues of apple trees. Plant Dis. 96:1645-1652. 